\title{
BALI TRADITIONAL SETTLEMENT MORPHOLOGY ANALYSIS PENGLIPURAN, KUBU VILLAGE, BANGLI REGENCY, BALI PROVINCE
}

\author{
HAKIM, Bhanu Rizfa ${ }^{1 *}$, SETIADI, Amos ${ }^{1}$ \\ ${ }^{1}$ Graduate Program, Universitas Atmajaya Yogyakarta, INDONESIA \\ *Corresponding author: Bhanurizfa@gmail.com
}

\begin{abstract}
Morphology settlement based on the traditional Balinese Hindu customs and beliefs that are used in laying out the pattern of settlement and thus creating harmonization .The development of the tourism potential of the Penglipuran village is benefited by the society as an attempt of promoting the uniqueness of the village. Issues raised in this research is how the morphology of the indigenous settlements on village Bali Penglipuran and factors that cause. The methods used in this research were direct observation, in-depth interviews, and mapping the physical environment of the area. This research has found the addition patterns and morphological changes in traditional settlements that are affected by the development of tourism. Hence, This study found the morphological characteristics of the indigenous settlements in Desa Adat Bali Panglipuran in an effort to uphold the order of the tradition.
\end{abstract}

Keywords: Penglipuran village; morphology; tourism village.

\section{INTRODUCTION}

Penglipuran traditional village is a village that still maintains beliefs and cultural elements. The village is situated in Kubu, Bangli District, Bali and is 45 kilometers away from Denpasar, or is 5.5 kilometers away from Bangli northwards. The total area is $160.63 \mathrm{ha}$, with the proportion of land use as follows: $9.23 \%$ Ha settlements, $30.85 \%$ Moor, and $46.77 \%$ forests, etc. In 2006, the number of villagers reached 897 inhabitants with 270 households, consisiting of 76 kramapengarep households, and the rest is kramapengerob households. Households categorized into kramapengarep have a responsibility in community planning, both in the yajna ceremony and planning and development of the village. Meanwhile, households belonging to kramapengerob have no specific right, but have the same duties and obligations as other inhabitants in general. The village is administered by traditional and customary law, with a kelian as the Chief, and two assistants called penyarikan, who regulates physical matters, and kancanroras, who manages niskalaor spiritual aspects; in running his duties, kancanrorasis led by a jerobayan (Arimbawa \& Santhyasa, 2010).

Similar to any other traditional village in Bali, in terms of architectural order, Penglipuran follows "Nawa Sanga" pattern, that is the incorporation of orientation, between the mountain and the sea toward wind direction. The village characterizes Bali Aga villages in general, with the most prominent trait is the presence of north-south linear axis functioning as open space. The open space divides the village into two parts, namely jejerbarat and jejertimur, oriented to "kaja-kelod" direction; it slopes upward, from the south to the north, oriented to Mount Batur (Prayogi, 2011). On the other hand, it can also be seen linkage patterns of the settlement with the concept of "Rwa bhineda" that exist in Hinduism, the two opposites like; sacred-profane, hulu- hilir, north-south, positivenegative, good-bad, and so on, which in reality has a value of harmony when sitting correctly. This concept is applied very carefully in the pattern of settlement whose primary goal is to achieve harmony and balance in life and berbhuana. (Alit, 2004).

This feature turns to be a tourist attraction and has brought Penglipuran village to be designated as a tourist village through Bangli Regent's Decree no 115 year 1993. The spatial layout of Penglipuran village needs to be maintained in order to remain sustainable as a tourist attraction; one of the efforts is controlling the use of space (Wulansari \& Suhirman, 2014).

In its development, the Village People Panglipuran continue to strive to maintain customs and culture in the throes of the modern era, the population increase and economic improvement of society and therefore contributes to the physical layout of the village. Planning and managing the physical layout village should remain based on the customs and culture (Hindu) so the village remains in tune and harmony. This study was conducted to analyze the morphology of the indigenous settlements Panglipuran village. This study will look at whether the development of morphology is still within the scope of the cultural elements of the arrangement of the traditional village of Bali along with aspects that influence. 


\section{LITERATURE REVIEW}

\section{Morphological Settlement of Balinese Traditional Village}

The realization of the traditional housing pattern as an artificial environment is strongly associated with the attitudes of the community life of Bali, not apart of the joints religion, tradition, belief and religious systems that underlie aspects of life. The role and influence of Hinduism in the arrangement of artificial environment, namely the religious implications of the various social life (Dwijendra, 2003).

The village settlement pattern, with variety in typology, generally represents parhyangan, pawongan and palemahan, which can be dichotomized into upstream (luan) and downstream (teben). Pawongan as a residential area has varying morphological patterns. The morphology is shaped by public infrastructures and facilities. The public infrastructures and facilities such as streets, electricity network, water supply, and telecommunications influence the morphology (Alit, 2004). Modern development also affects the morphological pattern of Penglipuran village, namely Home Office concept over the growing economy of the society. The current issue is the establishment of residential patterns influenced by active community responses to the environment. The responses are influenced by social, economic, cultural and policy factors, which will probably influence the culture systems, and the possibility for gradual shift or change, due to increasing status, developing social and economic systems, the growing of social and economic development, increased capacity development, and various needs to meet. Such changes can have an effect on the residential pattern. The changes can be found in the residential patterns in regional levels, starting from village to the smaller units (Alit, 2004).

\section{Residential Morphology Adat Bali}

The pattern of residential units as a residence has several buildings that make up the mass of natah. Natah reflection in the form of dwelling units: natah corrected, natah umah, natah Paon, natah jineng, and natah lebuh. Each Natah have meaning sacred and profane according to its function. Natah reflecting its disclosure related to the activity room house keeping life of the sacred to the profane activities. Judging from the orientation of the mass of the building in a yard occupancy and presence leads to the shrine occupies the main area. The layout of the holy places in a yard of a house to stay in the region of higher altitudes (kaja) and eastern (kangin). Pattern placement shrine still select the part of the mandala most important. (Alit, 2004).

\section{METHODOLOGY}

The research was a descriptive analysis using Tissue Analysis method by examining changes in morphology based on the development aspects stated accordingly. Data collection was done by (1) direct observation on the field to identify spatial patterns as well as physical and non-physical elements in the research location, (2) interviewing the related parties considered important and influential, namely the Chief of the Tribal Council under the topic of development of tourism in Penglipuran village, and (3) literature study on previous research findings concerning development patterns of the village, including searching for supporting statistical data.

\section{RESULT AND DISCUSSION}

Administratively, Penglipuran village is located in Kubu, Bangli district, Bali province. Penglipuran is situated $625 \mathrm{~m}$ above sea level and has moderate temperate, $24{ }^{\circ} \mathrm{C}$ averagely. The village has a fairly high rainfall, about $2000-2500 \mathrm{~mm} /$ year. The topography of the region is relatively sloping (the height difference ranges from 1 to $15 \mathrm{~m}$ ) from the north to the south. The width of the area is $112 \mathrm{Ha}$. Agriculture sector dominates most of the land use in the village. Then, the rest is used for forest, settlements, and sacred places (Wulansari \& Suhirman, 2014).

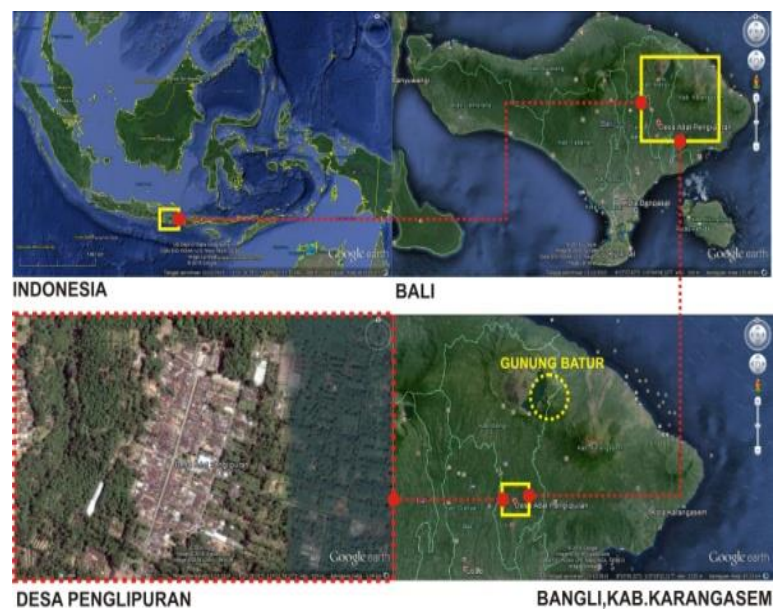

Source: google, 2016

Figure 1. Macro Map of Penglipuran Village 


\section{Spatial Layout of Penglipuran Village}

Penglipuran traditional village is formed based on Hinduism as reflected by the existence of kahyangan tiga (three heavens): Pura Penataran and Pura Puseh in the north and Pura Dalem in the south. In general, Kahyangan Tiga is usually on the three zones, where Pura Pusehis located in the main village (parahyangan), Pura Desain the middle (pawongan), and Pura Dalemin the back (palemahan). Thus, Parahyangan in the north is dedicated as a sacred area oriented to the mountain, while Palemahan in the south is planned as a less sacred area and oriented to the sea. The Mount Batur which becomes the centre, is located at the north of the village that is believed to magical and religious power. For Hindhu community in Bali, mountain is Gods' throne. The symbolic, imaginary orientation of the mountain is applied by positioning the northern part of the region/kaja as having the highest value the most sacred as shrines/ temples as stana (persemayaman) of God in his manifestation as the creator, that is so called Brahma and based in Pura Penataran, while Wisnu sits in village temple. Hence, mount/kaja typifies the Creator and the Sustainer. Meanwhile, the south/kelodis believed to have fusion power where Siwa occuplies; then, the villagers create stana (persemayaman) called Pura Dalem located on the village cemetery (Arimbawa \& Santhyasa, 2010)

Referring to (Prayogi, 2011) in his research, the Penglipuran traditional village follows Nawa Sanga pattern, i.e. mixed orientation between the mountain and the sea against wind direction. Penglipuran village is categorized into Bali Aga, with the most prominent feature is the presence of north-south with linear axis functioning as open space.

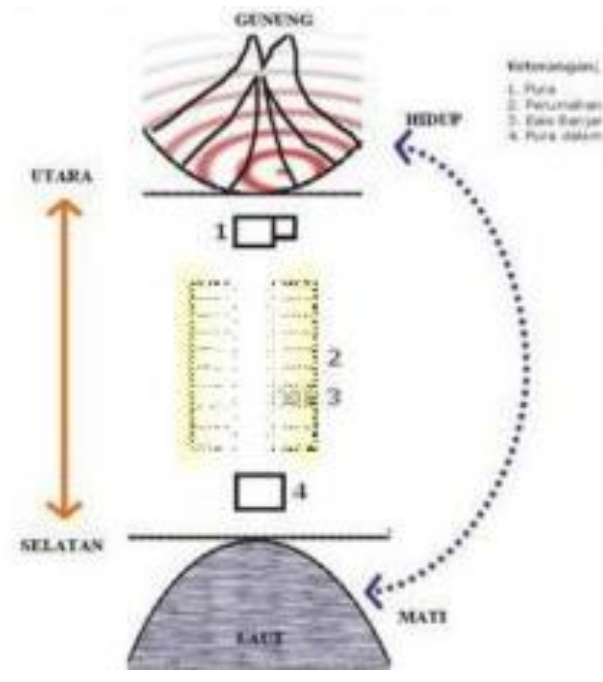

Source: Arimbawa \& Santhyasa, 2010

Figure 2. Orientation Symbolizing Mountain-Sea in Traditional Village Penglipuran
Open space separates the village into two parts: jejerbarat and jejertimur, with kaja-kelod concept, from the south to north orientated to Mount Batur. Symbolically, spatial patterns of Penglipuran village is divided into three areas, with different levels of sacredness (Tri Mandala), namely:

a. Mandala Utama: it is the most sacred area, which lies in the north of the village or the highest land and is the area dedicated to deities/ancestors. This space is located in Pura Penataran, Pura Puseh and other temples found at the north and rast of the bamboo forest.

b. Madia Mandala: it is the second area where the villagers functionit as a residential area. In this part, there are several sacred zones: Pura Ratu Pingit, Pura Balai Banjar, Pura Dadia Dalem Tampuagan and Balai Banjar. At the south, there is a monument having open spaces and meeting hall, which annually is used as a Memorial of the death of the Bangli hero "Anak Agung Anom Jaya Mudita" and other memorial days.

c. Nista Mandala: it is the third part that lies in the southern most of the village. This place is functioned for public cemetery. In this area, there is also a holy building, namely Pura Dalem Temple (Pelapuhan), Pura Prajapati and Pura Ratu Mas Ayu Manik Melasem.

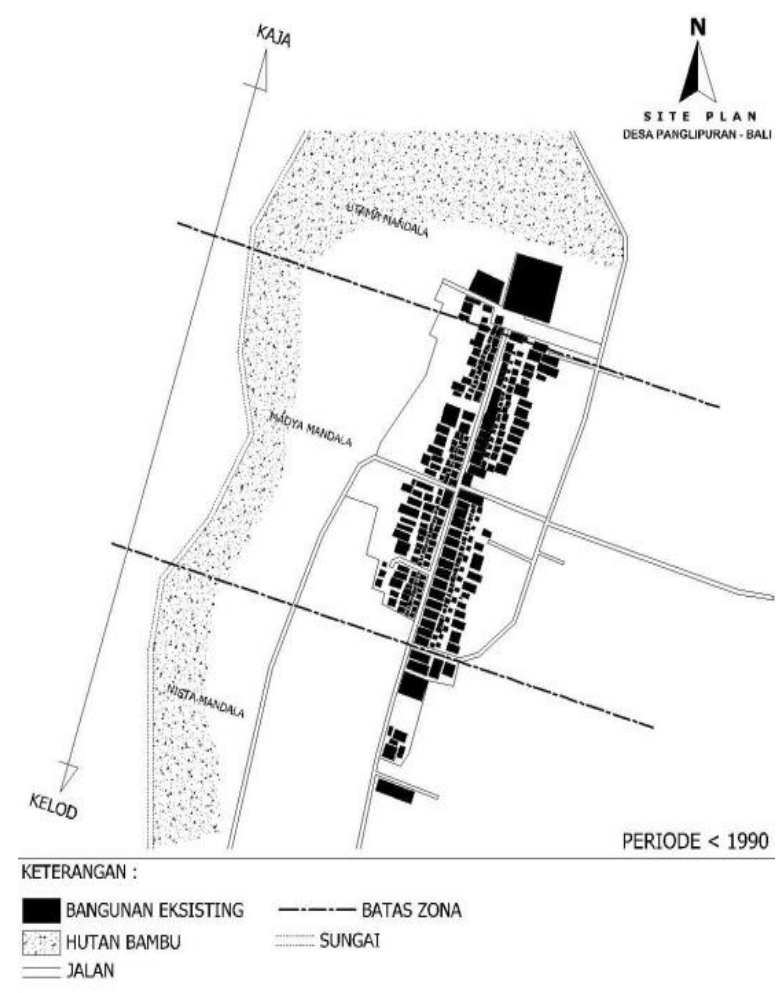

Source: Dwijendra, 2009

Figure 1. Interpretation of the Spatial Layout of Penglipuran village before established as a tourist village 
New modern architecture penetrated the village when the Government began to build up Taman Makam Pahlawan (Heroes Cemetary) in the early 1990s, and then continued to set up schools, streets, electricity network, water supply, telephone, and etc. (Dwijendra, 2009).

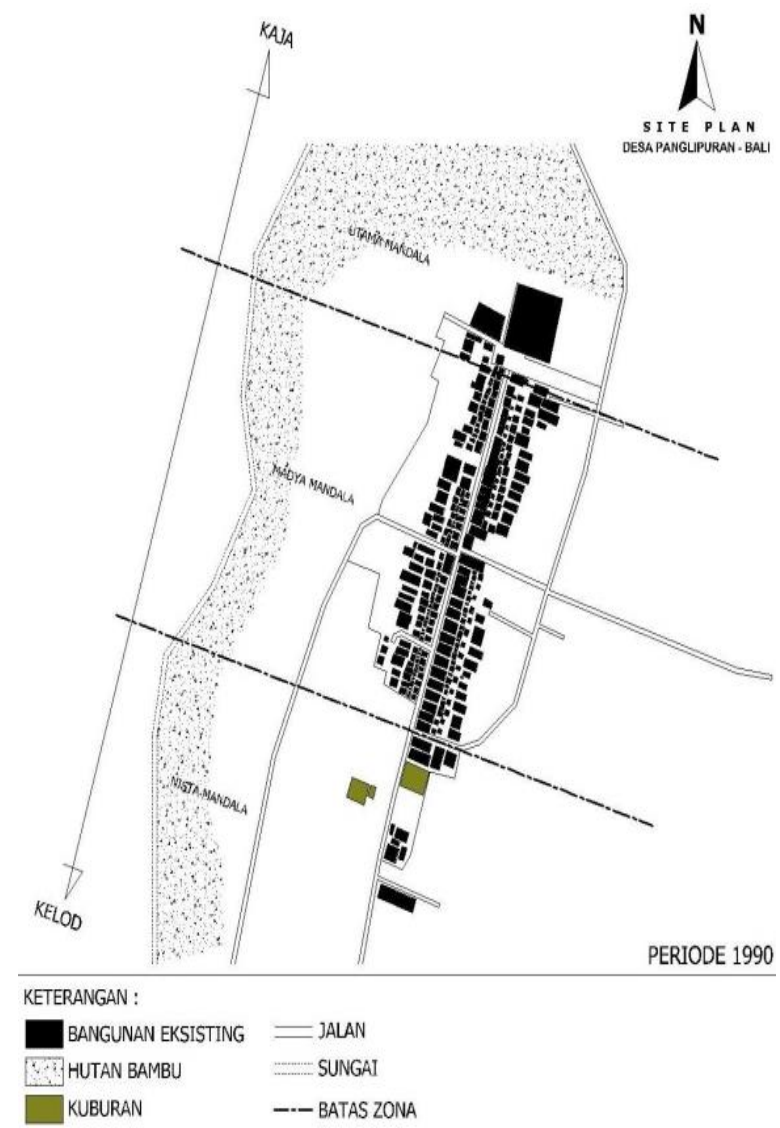

Figure 2. Location of Heroes Cemetary as a starting point in Developing Penglipuran Village in 1990

\section{The addition of facilities in the village that} supports potential area

The construction of Heroes Cemetary became the milestone of development in the village since 1995, that continued to advance and to improve by adding more amenities, allowing the village to be crowned the 3rd World's Cleanest Village.

\section{Sacred Places}

The addition of temples is the solution for Penglipuran villagers to worshipping.

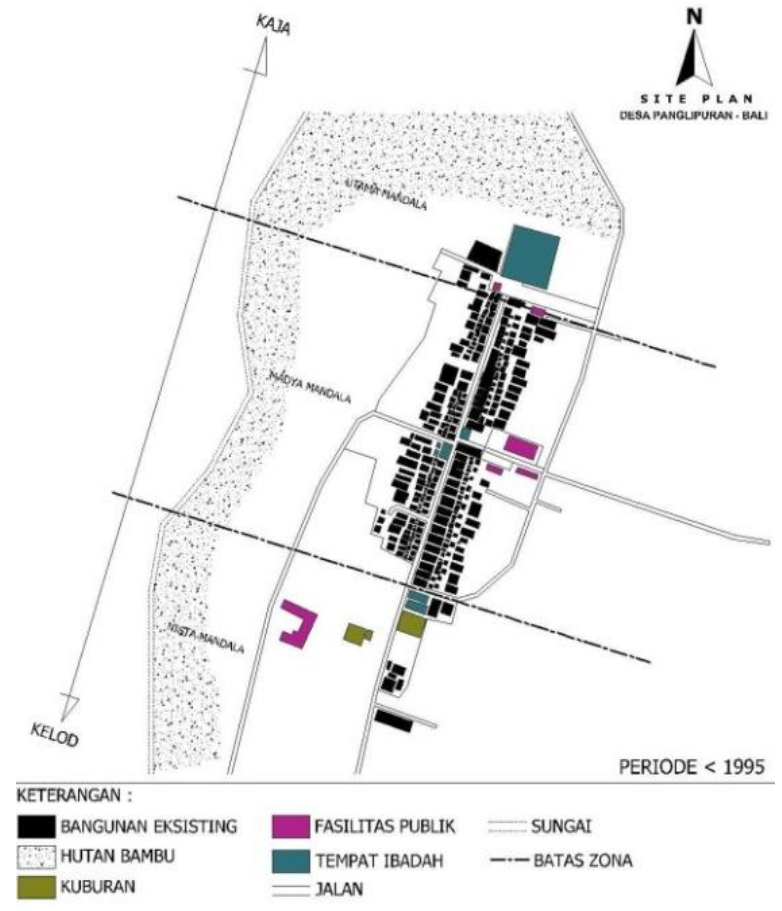

Figure 3. Development of Temples in 1995 as Places for Worshipping

\section{Public Facilities}

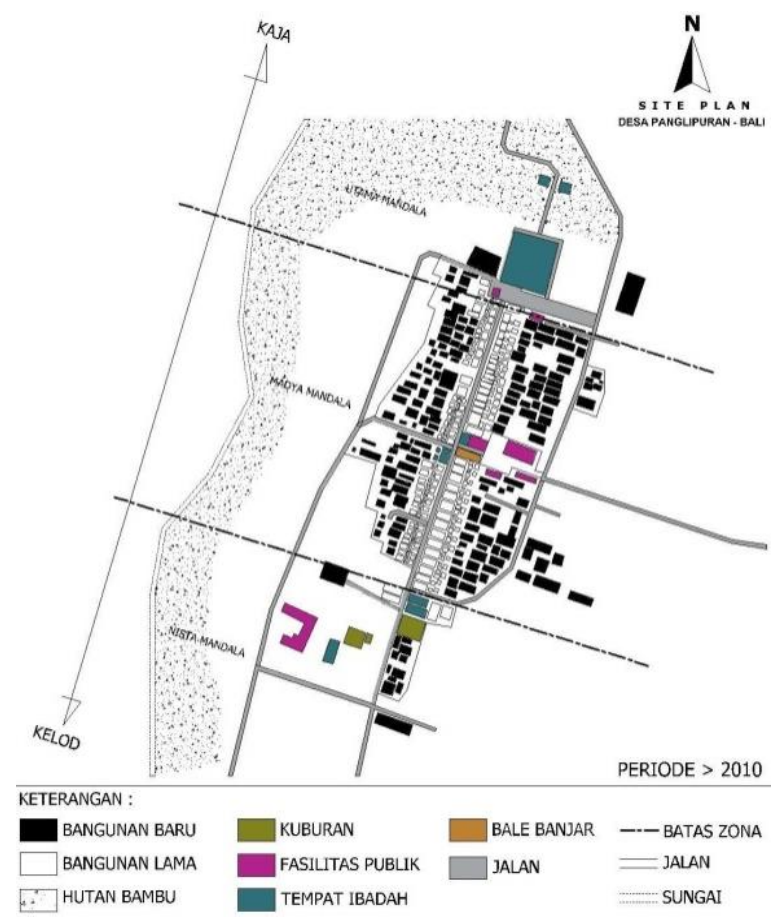

Figure 4. Development of Public Facilities in PenglipuranVillage in 2010 
Changes in Streets and Houses Pattern of Penglipuran village Influenced by the Modern Concept

The pattern of streets and development of residences are affected by tourism potential development in Penglipuran village. In terms of physical aspect, this village offers improvement in the bamboo forest with the addition of pathways for visitors who want to enjoy the scenery. The development of such potential is also fruitful and impacts othernon physical aspects, i.e. economic, social and cultural aspects. From the economic aspects, the societies, who were initially farmers, developed and benefitted from the bamboo forest by becoming craftsmen; in addition, many other professions are evolving, such ascivil servants, merchants, entrepreneurs and others. The socio-cultural aspect is also influenced, as characterized by autonomy mandated by the government to the village authority to expand and improve the economy in the community.

Penglipuran village embraces kalapatra concept during its development affected by tourism potential; this village tries to combine place, time, situation, condition and tolerance. Despite growing as traditional society, Penglipuran village community also advances in terms of transport, which is marked with the street pattern that encircles the village (so-called Ring Road), thus motor vehicle can go through the ring road. The new streetpattern is followed by the increasing economy of the community from tourism. Recently, many villagers have private vehicles and an adequate place to live with the growing number of occupants per residence. Most village inhabitants heighten the mass buildings, so-called home office, which includes garage and additional spaces such as rooms with modern concept (Supat, 2016)

\section{Residential Pattern in Penglipuran Village}

In regards to (Prayogi, 2011) in a micro scale, the spatial using Tri Mandala concept is reflected on the spatial pattern in Penglipuran village, namely:

a. Utama Mandala: It is the most sacred spot, located in the northeast of the yard. In this area, there is a family building/temple.

b. Madia Mandala: It is the second part to be used for daily activities, with its traditional buildings such as:

1) Kitchen: on the north, and is also used as a bed for those already aged.

2) Balai Saka Enam: on the South, as a place of Yajna such as Manusia Yadnya, Pitra Yadnya, and other rites.

3) Loji Building: on the West, it is where the family the rests. c. Nista Mandala: It is the third part of yard. This area is where toilet is situated, near the livestock stall.

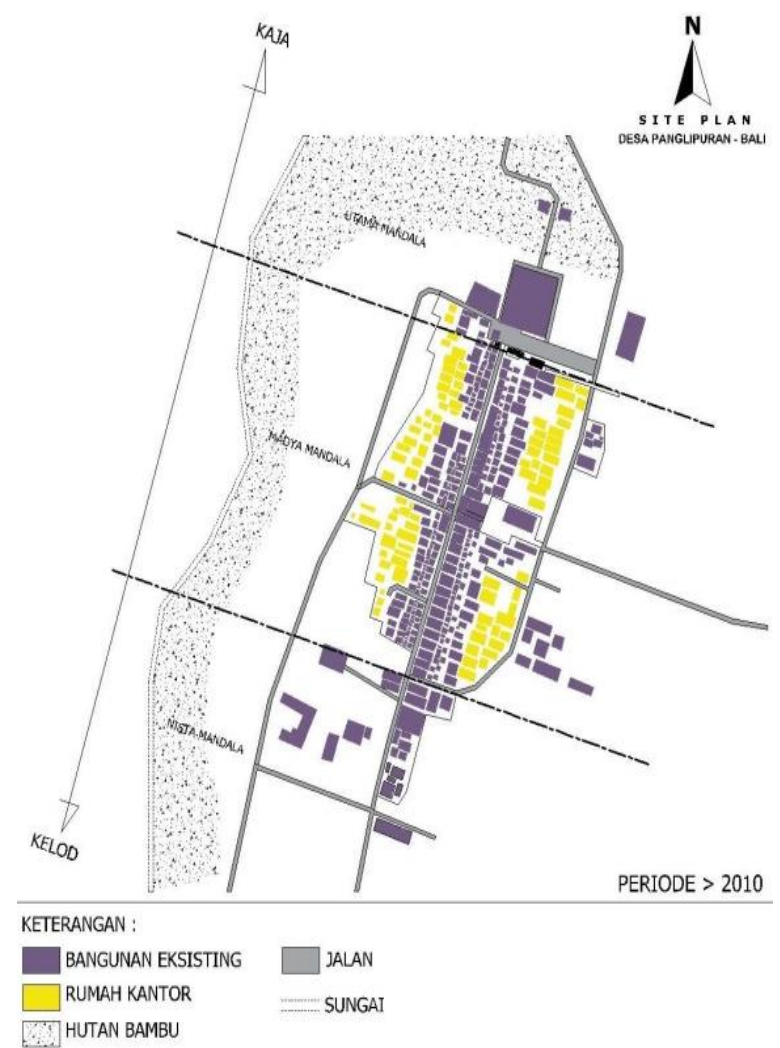

Figure 5. Development of Street and Home Office in Penglipuran Village in 2016

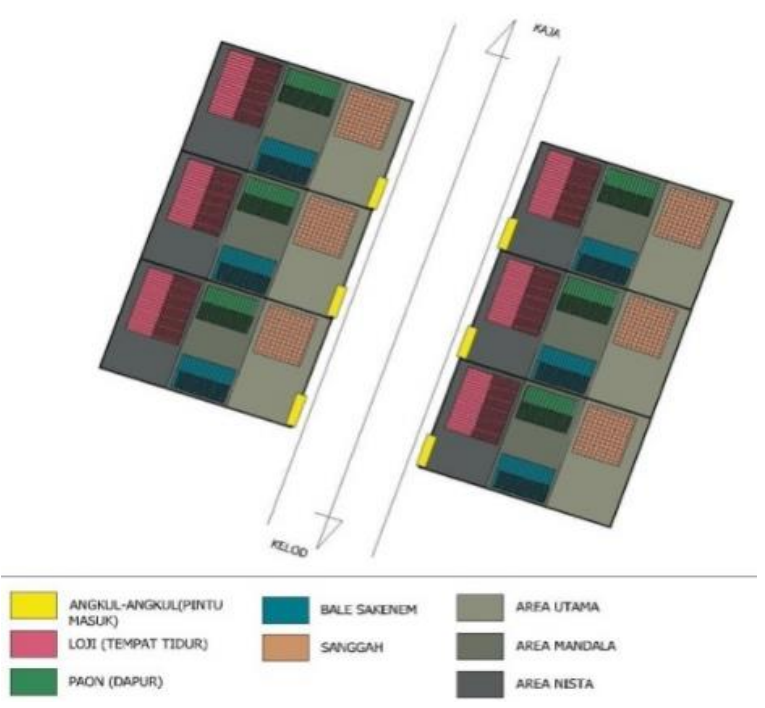

Figure 6. Residential pattern of Penglipuran Village

The establishment of art shops in the people's house yard also has affected the traditional values of the building architecture of the people in Penglipuran village due to the addition of a building in the house. 


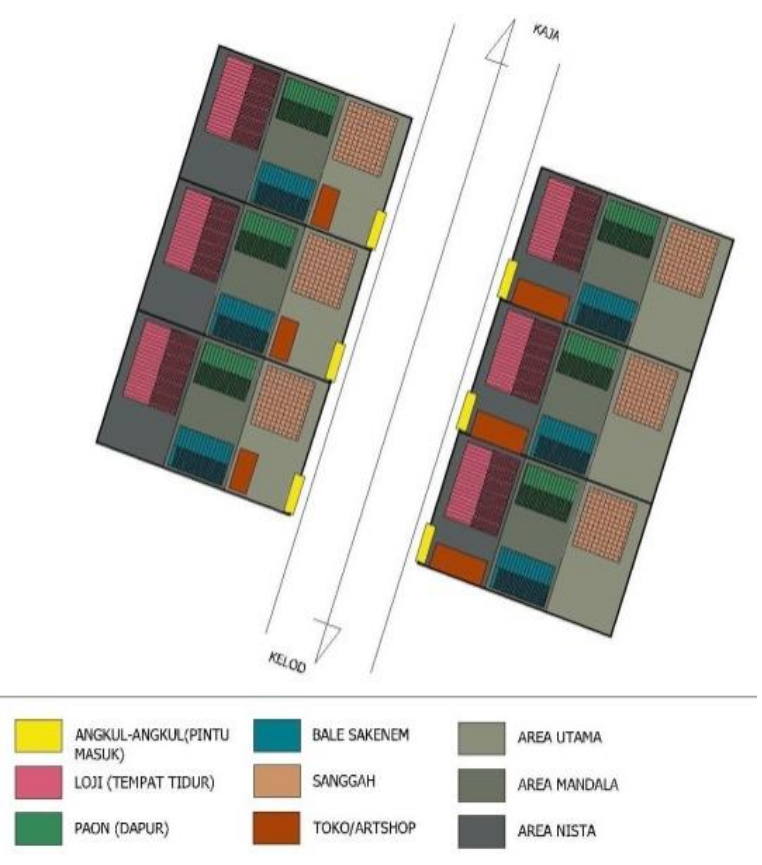

Figure 7. Residential Patterns in Penglipuran Village after the addition of art shops

The addition of urban residential units morphologically appear to be clearly seen from the patterns of mass building, orientation and land tenure. In deciding the building mass, the people apply sanga mandala concept but with variations and changes caused by economic needs. This is especially noticeable in the primary zone that is located on the road side, which was initially a sacred zone transformed into garage, shops, stalls, and so on. The effort of maintaining the number of building masses in creating natah still appears mainly on the vast grounds, where the builing mass can be more than 3 (three) times of the standard mass. The attempt to creating natah is generally the result of idealism associated with the ordinances as well as traditional and religious ceremonies (Alit, 2004).

Morphological development in Penglipuran village still gives priority to nawasanga rules as a factor in upholding the culture that has developed hereditarily. Development of tourismin the village also contributes to the morphological development, in both macro and micro scales, as tourism has maximized the potential of the village in economic, social and cultural matters.

Economy can be viewed from macro scale, such as the growing emergence of handicraft centres and also art shops managed by local citizens. From the social and cultural sides, there are some schools built as the center of education in the village, balaior village hall as meeting point for cultural events, open space to rest, more temples built to support worship- ing activity, and street development as an anchor of economic growth of the community.

Expansion of facilitiesis a manifestation of the growing tourism potential, but it is still within the nawasanga scope. Art shops are placed in Madya Mandala zone as the second part of a house; locating in the same zone are balaibanjar and open space. In a micro scale, advancement in art shops that are found almost inresidents' houses do not undermine the concept of nawasanga; in the houses lying on the eastern side, the art shop is situated in area nista, the area in front of angkul - angkul, while for houses in the western area, the art shops will be situated in the main area in front of angkul-angkul, at the southern side of sanggah. Hence, the art shops do not violate the rules in nawasanga concept as practiced in Penglipuran village.

\section{CONCLUSION}

a. Rural development Penglipuran morphology was influenced by economic, social and cultural. The influence is strengthened by abundant supplies of craft centres, art shops, schools and temples, improvements on the village street.

b. Some of the visible morphological patterns are addition and improvement of facilities enhancing the infrastructure, such as schools, temples, pathways in the forests and tourist resting place.

c. Morphological changes in the settlement patterns take place because the village embraces kalapatra concept; however, in addition to the traditional society, the society in the village welcomes the elements of modernization, so there are areas that still preserve the culture and traditions, and also others that hold modern elements as influenced by economic level, where the people need an area in their house to park the vehicles and the addition of the mass of the building not part of the tri hita mandala concept.

d. The concept of kalapatra can be adopted by other tourist villages that still need to maintain cultural and traditional elements without neglecting possible influences of modernization.

\section{REFERENCES}

Alit, I. K. (2004). Morfologi Pola Mukiman Adati Bali. Jurnal Permukiman "Natah", 2(2), pp.56107.

Arimbawa, W. \& Santhyasa, I. K. G. (2010). Perspektif Ruang Sebagai Entitas Budaya Lokal Orientasi Simbolik Ruang Masyarakat Tradisional Desa Adat. Local Wisdom. Jurnal Ilmiah Online, Issn: 2086-3764, II (2010), pp.1-9. 
Dwijendra, N. K. A. (2003). Perumahan dan Permukiman Tradisional Bali. Jurnal Permukiman "Natah", 1(1), pp.8-24.

Dwijendra, N. K. A. (2009). Arsitektur Kebudayaan Bali Kuno. Denpasar, Bali: Udayana University Press.

google. (2016, June 6). google. Retrieved from: http://www.googleearth.com

Prayogi, P. A. (2011). Dampak Perkembangan Pariwisata di Objek Wisata Penglipuran. Jurnal Perhotelan Dan Pariwisata, 1(1), pp.64-79.
Supat, I. W. (2016). Potensi wisata Desa penglipuran. (April 18) (B. R. Hakim, Interviewer).

Wulansari, T. R. \& Suhirman (2014). Perbandingan Pengendalian Pemanfaatan Ruang Tradisional di Desa Adat Penglipuran, Kabupaen Bangli dengan Pengendalian Pemanfaatan Ruang Formal. Jurnal Perencanan Wilayah Dan Kota A SAPPK, 3(1), pp.156-169. 